\title{
Polysemy and Homonymy: Challenges Relating to Lexical Entries in the Sesotho sa Leboa- English Bilingual Dictionary*
}

\author{
V.M. Mojela, Sesotho sa Leboa National Lexicography Unit, University of \\ Limpopo, Turfloop Campus, Polokwane, Republic of South Africa
}

(mojelav@ul.ac.za)

\begin{abstract}
This article outlines the challenges relating to the lemmatization of the lexical items which are either polysemous or homonymous, as experienced during the compilation of the Sesotho sa Leboa-English Bilingual Dictionary. These problems can be ascribed to a lack of objectivity resulting from an inadequate knowledge regarding the etymological relationships of the meanings of some lexical items which are subsequently misclassified as either homonyms or polysemous words. This often causes improper lexical entries in dictionaries, i.e. polysemous words may be lemmatized as homonyms and vice versa.

To unambiguously distinguish between lexical items which are either homonyms or polysemous words, lexicographers should in this regard consider the criteria suggested by scholars:

- In accordance with the relatedness/unrelatedness criterion, the lexicographer will need to determine the extent to which the lexical items are related before entering them in the dictionary.

- The etymological criterion will help the lexicographer to determine the relatedness of the lexical items for inclusion in the dictionary according to their historical connection.

Using these criteria to lemmatize a lexical item properly in the dictionary, the lexicographer will be required to determine whether a lexical item can be regarded as one word with more than one meaning (a polysemous word), or as two different lexical items which have the same spelling (homonyms). To make this distinction, the lexicographer will need to research the historical background of the lexical item. Even though these criteria are important aids for distinguishing polysemy and homonymy, the problem of subjectivity is not altogether removed since the criteria do not specify the level or degree of relatedness/unrelatedness at which the lexical item(s) can be said to be polysemous or homonymous.
\end{abstract}

Keywords: SEMANTIC SHIFT, POLYSEMY, HOMONYMY, MEANING, SENSE RELATION, LEXICAL ITEM, ETYMOLOGY, METAPHOR, METAPHORIC SENSE, EUPHEMISM, LEMMATIZATION

* This article was presented as a paper at the Eleventh International Conference of the African Association for Lexicography, organized by the Tshivenda National Lexicography Unit, University of Venda for Science and Technology, Thohoyandou, Republic of South Africa, 5-7 July 2006. 
Opsomming: Polisemie en homonimie: Uitdagings betreffende leksikale inskrywings in die Sesotho sa Leboa-English Bilingual Dictionary. Die artikel skets die uitdagings betreffende die lemmatisering van leksikale items wat óf poliseem óf homoniem is soos teëgekom gedurende die samestelling van die Sesotho sa Leboa-English Bilingual Dictionary. Hierdie probleme kan toegeskryf word aan 'n gebrek aan objektiwiteit wat die gevolg is van 'n onvoldoende kennis aangaande die etimologiese verwantskappe van die betekenisse van sommige leksikale items wat gevolglik foutiewelik geklassifiseer word as ó homonieme óf poliseme woorde. Dit veroorsaak dikwels verkeerde leksikale inskrywings in woordeboeke, d.w.s. poliseme woorde mag as homonieme gelemmatiseer word en andersom.

Om ondubbelsinnig te onderskei tussen leksikale items wat óf homonieme ó poliseme woorde is, behoort leksikograwe in dié verband die kriteria te oorweeg wat deur vakkundiges voorgestel is:

- In ooreenstemming met die verwantskaps-/nieverwantskapskriterium sal dit vir die leksikograaf nodig wees om te bepaal watter leksikale items verwant is voordat hulle in die woordeboek ingesluit word.

- Die etimologiese kriterium sal die leksikograaf help om die verwantskap van leksikale items vir insluiting in die woordeboek te bepaal volgens hul historiese samehang.

Deur hierdie kriteria te gebruik om 'n leksikale item korrek in die woordeboek te lemmatiseer, sal van die leksikograaf vereis word om te bepaal of 'n leksikale item beskou kan word as een woord met meer as een betekenis ('n poliseme woord), of as twee leksikale items wat dieselfde spelling het (homonieme). Om hierdie onderskeid te tref, sal die leksikograaf die historiese agtergrond van die leksikale item moet navors. Selfs al is hierdie kriteria belangrike hulpmiddels vir die onderskeiding van polisemie en homonimie word die probleem van subjektiwiteit nie heeltemal oorkom nie, omdat die kriteria nie die vlak of graad van verwantskap/nieverwantskap aandui waarby die leksikale item(s) as poliseem of homoniem beskou kan word nie.

Sleutelwoorde: BETEKENISVERSKUIWING, POLISEMIE, HOMONIMIE, BETEKENIS, BETEKENISVERWANTSKAP, LEKSIKALE ITEM, ETIMOLOGIE, METAFOOR, METAFORIESE BETEKENIS, EUFEMISME, LEMMATISERING

\section{Introduction}

It is not always possible to distinguish polysemous lexical items from homonyms, and whenever this distinction is made, subjectivity prevails. The lexicographer's knowledge of the etymological development of the lexical items is of vital importance. In fact, the lexicographer shows the distinction made by entering homonyms separately in the dictionary, i.e. as two or more different lexical items even though the lexical items have the same spelling and/or pronunciation, while a polysemous lexical item is entered as one lexical item with its definition showing all its multiple meanings, i.e. two or more meanings attached to one lexical item.

\section{Defining polysemy and homonymy}

Several linguists, semanticists and lexicographers define polysemy and homon- 
ymy accurately in academic and scientific researches. Stern (1931), Ullman (1962), Lyons (1977), Leech (1981), Hurford and Heasley (1983), Taylor (1989), and Louwrens (1994) are among those scholars who researched these sense relations. According to Leech (1981: 228), homonyms are 'roughly two or more words having the same pronunciation and/or spelling, but different in meaning'. This definition of homonymy is in line with that of Macdonald (1977: 625) who defines a homonym as 'a word having the same sound and perhaps the same spelling as another, but a different meaning and origin'.

From these definitions it can be deduced that homonymy covers both written and spoken forms, but it is possible to have partial homonymy (or heteronymy), where the identity is within a single medium as in homography and homophony (Crystal 1991: 167). The Encarta Concise English Dictionary (2001) defines a homograph as 'a word that is spelt in the same way as one or more other words but is different in meaning' and a homophone as 'a word that is pronounced in the same way as one or more other words but is different in meaning and sometimes spelling'.

In Sesotho sa Leboa there are, however, also tonal changes which need to be considered when describing homonyms. If two or more words are spelt the same, the tonal patterns must also be taken into account: heterotonal homonyms have different tonal patterns (Louwrens 1994: 75), while homotonal homonyms have the same tonal pattern (Louwrens 1994: 76).

The following are examples of two groups of words spelt the same in Sesotho sa Leboa:

$\begin{array}{ll}\text { fola } & \text { cool down } \\ \text { fola } & \text { line up (to queue) } \\ \text { fola } & \text { smoke (a pipe, cigarette, etc.) } \\ \text { fola } & \text { samp, crushed maize } \\ \text { mogolo } & \text { salary } \\ \text { mogolo } & \text { throat }\end{array}$

The words in the first group of four, however, do not have the same pronunciation: the first two are pronounced with the mid-low vowel $/ \mathrm{s} /$, therefore /fola/, while the last two are pronounced with the mid-high vowel /o/, therefore /fola/. But when the tonal patterns of these two pairs of words are considered, the following variations emerge:

[fola]: fólà 'cool down' (high-low tone) and folà 'line up' (low-low tone), and

[fola]: folà 'smoke' (low-low tone) and fólà 'samp, crushed maize' (high-low tone).

The words in this group are therefore heterotonal homonyms.

When the pronunciation and tonal patterns in the second group of two are investigated, it appears that they are the same in each case. Both words have the pronunciation /moyols/ and the tonal pattern mògòlò (low-low-low). The 
words in this group are therefore homotonal homonyms.

According to Taylor (1989: 103), homonymy occurs when unrelated meanings attach to the same phonological form. He distinguishes two ways in which homonymy is usually brought about, i.e.

(a) firstly, related meanings of a once polysemous word have drifted so far apart that there is no perceived relationship between them, and

(b) alternatively, unrelated words which were once phonologically distinct have been subject to the 'blind' operation of sound change, and in the course of time have become phonologically identical.

Hurford and Heasley (1983: 123) say that a case of polysemy is one where 'a word has several very closely related senses'. And Mojela (1991: 31) also explains it as a case where 'one word may have a set of more than one different but related meanings'. According to Taylor (1989: 99), polysemy is the association of two or more related senses with a single linguistic form. Illustrating it with an example, he says: 'The word "bird" can refer to many different kinds of creature - robins, penguins, ostriches, etc. These different kinds of creature are members of the category in virtue of similarity to a single prototype representation.'

\section{Lexicographic challenges}

The major challenge facing lexicographers is the making of a clear and objective distinction between polysemous and homonymous lexical items which are entered as lemmata in their dictionaries. Such a distinction is not always possible with all lexical items in a language. Lexicographers with little knowledge of the etymology of the lexical items in their languages will have problems in entering polysemous and homonymous lexical items in their dictionaries, since they will not know the extent to which the lexical items are related. In this regard, Lyons (1977: 550) says the following: 'The difference between homonymy and polysemy is easier to explain in general terms than it is in terms of objective and operationally satisfactory criteria.'

Lyons' statement shows that the distinction between polysemy and homonymy is more complex than is generally perceived. He gives two criteria to simplify the complexities of identifying polysemy from homonymy, i.e.

- the etymological criterion, and

- the relatedness/unrelatedness criterion.

\section{The etymological and relatedness/unrelatedness criteria}

With these criteria, the lexicographer's knowledge of the etymological development (or history) of lexical items will help in identifying their origin and 
their relationships for entering them in the dictionary as homonyms or polysemous lexical items. The etymological criterion will assist the lexicographer in establishing whether the lexical items developed or originated from what Taylor (1989: 103) regards as 'related meanings of a once polysemous word which have drifted apart'. The origin and relationship between the following groups of lexical items can be considered:

$\begin{array}{ll}\text { tshela } & \text { jump } \\ \text { tshela } & \text { six } \\ \text { tšhela } & \text { pour (liquid, sand, etc. into a container) } \\ \text { tšhela } & \text { pay tax } \\ \text { šupa } & \text { seven } \\ \text { šupa } & \text { (to) point }\end{array}$

The etymological analysis of the lexical item tshela 'six' will show that the word originated from tshela 'jump'. Counting in the Sotho tradition is done with the help of the fingers starting with the fingers of the one hand, and when the fifth finger is reached, 'jumping' to the other hand to find the sixth finger, in this way giving the number tshela 'six' its name. Obviously, the lexicographer with little (or no) knowledge of the etymology of this lexical item will enter tshela twice as two unrelated homonymous lexical items, i.e.

$$
\begin{array}{ll}
\text { tshela } & \text { jump } \\
\text { tshela } & \text { six }
\end{array}
$$

while the knowledgeable lexicographer will enter it as one polysemous lexical item with two related meanings, i.e.

$$
\text { tshela jump }
$$

The etymological investigation of the lexical items tšhela 'pour (liquid, sand, etc.)' and tšhela 'pay tax' reveals that the second lexical item originated from the first one. The pouring of money into the tax-collector's coffer is metaphorically compared to the pouring of liquid, sand, etc. into a container. In this way, the two meanings become related, so that tšhela should be regarded as a polysemous lexical item.

The etymological relationship between the meanings of šupa 'seven' and šupa 'to point' can be explained by the fact that the number seven got its name from the seventh finger, which is used for pointing. The seventh finger or the 'pointing finger' is also referred to as tšhupa baloyi, which means the finger used to point out witches/wizards, i.e. to indicate who performed witchcraft/wizardry. Therefore, this relationship between šupa 'seven' and šupa 'to point' gives the lexicographer a reason to enter šupa as a polysemous word instead of two homonymous words. 


\section{Subjectivity associated with polysemy and homonymy}

As a result of identification problems, objectivity will not always be possible for lexicographers dealing with polysemous and homonymous lexical items. Consequently, the lexical items which one lexicographer might regard as polysemous, the other one might see as homonymous. As Lyons (1977: 550) puts it: 'Relatedness of meaning is a matter of degree. Those lexical items which one person might regard to be semantically related to a certain degree, the other person might see them to be very far apart.'

This is especially the case when the lexicographer must decide about the degree to which the 'related meanings of a once polysemous word have drifted ... apart' so that there is 'no perceived relationship between them' (Taylor 1989: 103). The decision on how far words have drifted apart is mainly based on subjectivity. The following groups of lexical items can be discussed as examples:

$\begin{array}{ll}\text { tšhoša } & \text { frighten, terrorize } \\ \text { tšhoša } & \text { weapon (which frightens, terrorizes) } \\ \text { makarapa } & \text { helmets } \\ \text { makarapa } & \text { migrant workers from the Witwatersrand } \\ \text { dirapa } & \text { gardens } \\ \text { dirapa } & \text { game reserves } \\ \text { dirapa } & \text { graveyards }\end{array}$

Lexicographers will not to the same degree perceive the shift which has occurred in the meanings of the 'once polysemous lexical item' tšhoša, i.e. 'to frighten, terrorize' and 'a weapon (which frightens, terrorizes)'. While one will regard these meanings to be related because tšhoša for 'a frightening weapon' originated from the metaphoric use of tšhoša 'frighten', the other will consider the two meanings to have drifted 'so far' apart that they should be regarded as homonyms, because 'weapon', which is a noun, cannot be associated with a verb 'frighten'.

Makarapa 'helmets' (singular: lekarapa) are safety hats worn by workers in the mines. Most of the men from the rural areas worked as migrant labourers in the Witwatersrand area. In those days, it was prestigious to work in the mines, returning during Christmas holidays (usually with a lot of money). That is why most of the returning migrant workers wore their helmets (makarapa) to show that they come from the mines. As a result, the name for the migrant worker's helmet lekarapa (plural: makarapa) metaphorically came to refer to the migrant worker himself.

The same semantic shift from what may be regarded as a polysemous relationship to a homonymous relationship is found in the lexical item dirapa 'gardens', 'graveyards', and 'game reserves'. The original meaning of dirapa is 'gardens'. As a result of euphemism and metaphoric associations, dirapa came 
to refer also to 'graveyards' and 'game reserves'. The meaning shift is so drastic that only the researcher with a knowledge of the etymology of this lexical item would be able to trace the relationship between the three meanings of dirapa.

\section{Conclusion}

The main objectives of this article can be summarized by the answers to the following questions:

- Are lexicographers aware of the complications pertaining to the identification and the ultimate distinction between polysemy and homonymy?

- Do lexicographers realize that it is very difficult, if not impossible, to be objective in distinguishing between homonymy and polysemy?

- Are lexicographers aware of the importance of having sufficient knowledge of the etymological history of lexical items before distinguishing between polysemous and homonymous lexical items?

- Do lexicographers know that relatedness of meaning is only measured in degrees, and that the degree to which lexical items are related depends on the individual researcher's subjective conclusion?

A knowledge of the suggested criteria for identifying polysemy and homonymy is important in making a distinction between these two sense relations, but this does not always solve the question of subjectivity in distinguishing between polysemy and homonymy, since the criteria are always associated with the semantic relationship of the lexical items. Furthermore, it is obvious that the lexicographer will be faced with numerous lexical items for which it will not always be possible to trace the etymological history.

\section{References}

Crystal, D. 1991. A Dictionary of Linguistics and Phonetics. Third Edition. Oxford/Cambridge, Mass.: Blackwell Publishers.

Hurford, J.R. and B. Heasley. 1983. Semantics: A Coursebook. Cambridge: Cambridge University Press.

Leech, G. 1981. Semantics: The Study of Meaning. Harmondsworth: Penguin Books.

Louwrens, L.J. 1994. Dictionary of Northern Sotho Grammatical Terms. Pretoria: Via Afrika.

Lyons, J. 1977. Semantics, Volumes 1 and 2. Cambridge: Cambridge University Press.

Macdonald, A.M. 1977. Chambers Twentieth Century Dictionary. Bath: Pitman Press.

Mojela, V.M. 1991. Semantic Changes Accompanying Loan-words in the Northern Sotho Lexicon. Unpublished M.A. Dissertation. Pretoria: Vista University.

Rooney, K. (Ed.-in-chief). 2001. Encarta Concise English Dictionary. London: Bloomsbury.

Stern, G. 1931. Meaning and Change of Meaning. Gothenburg: Goteborgs Hogskolas Arrskrift.

Taylor, J.R. 1989. Linguistic Categorization: Prototypes in Linguistic Theory. Oxford: Clarendon Press.

Ullman, S. 1962. Semantics: An Introduction to the Science of Meaning. Oxford: Basil Blackwell. 